\title{
Electrophoretic Patterns of Strains of Mycoplasma pulmonis
}

\author{
By KATHR YN A. FORSHAW* \\ Department of Pathology, Ruchill Hospital, Glasgow, G20 9NB
}

(Received 25 June 197I; revised 3 March 1972)

SUMMAR Y

Strains of Mycoplasma pulmonis, examined by polyacrylamide-gel electrophoresis of proteins extracted in a phenol-acetic acid-water solvent, gave patterns with reproducible differences. Some strains could be placed into groups, but a number could not be associated with any group. In all but one case a 'basic $M$. pulmonis pattern' was easily recognizable. This exception suggests that occasionally one might fail to recognize a strain of $M$. pulmonis by relying solely on the electrophoretic technique.

\section{INTRODUCTION}

Fowler, Coble, Kramer \& Brown (I963) suggested that the electrophoretic separation of proteins of mycoplasmas be used as a new method of identifying members of this species. Their observations were extended by Rottem \& Razin (1967). The patterns obtained by these workers were distinct for the species of mycoplasmas examined. Sometimes there were differences between the electrophoretic patterns of strains within a species; for example, $\mathrm{Myco}$ plasma pulmonis (Razin \& Rottem, 1967; Razin, I968).

In the present investigation I9 strains of Mycoplasma pulmonis were examined by polyacrylamide-gel electrophoresis to find out to what extent the electrophoretic patterns of their proteins differed and to see if a typing scheme could be formed on the basis of these patterns.

\section{METHODS}

Organisms. The strains of mycoplasmas and the sources from which they were obtained are given in Table $\mathrm{I}$. The strains included reference strains and recent isolates. Preliminary identification of recently isolated strains was made by the growth inhibition test (Clyde, 1964) employing at least two antisera to Mycoplasma pulmonis plus antiserum to the other rodent mycoplasmas $M$. neurolyticum and $M$. arthritidis. Strains which were inhibited were regarded as members of the species $M$. pulmonis.

Clones. All strains were cloned at least three times. Where an original culture showed several colonial forms, representative colonies were cloned six times.

Media and growth conditions. The media used for the cultivation of the mycoplasmas were modified from that described by Chanock et al. (1962). Thallous acetate was omitted and ampicillin at a final concentration of $0.1 \%$ was used in place of penicillin (Fallon, 1969). Medium which contained I \% (w/v) glucose and $0.002 \%$ phenol red was inoculated from a logarithmic phase culture and incubated aerobically at $37^{\circ} \mathrm{C}$ until a colour change in the medium showed a drop of $0.5 \mathrm{pH}$ unit, which took approximately $48 \mathrm{~h}$. For solid medium $\mathrm{I} \%$ (w/v) Ionagar no. 2 (Oxoid) was added.

* Present address: Salmonella Reference Laboratory, Central Public Health Laboratory, Colindale Avenue, London, NW9 $5 \mathrm{HT}$. 
Table r. Sources of Mycoplasma strains used

\begin{tabular}{|c|c|c|c|}
\hline Species & Strain & Site of recovery & Source \\
\hline $\begin{array}{l}\text { Mycoplasma pulmonis } \\
\quad \text { (I) Established strains }\end{array}$ & $\begin{array}{l}\text { Negroni } \\
\text { Ash } \\
\text { Kon } \\
880 \\
\text { M2 } \\
\text { M50 } \\
\text { M72L } \\
63 \\
47 \\
\text { Sabin type C } \\
\text { Cheng }\end{array}$ & $\begin{array}{l}\text { Tissue culture } \\
\text { Rat lung } \\
\text { Rat lung } \\
\text { Tissue culture } \\
\text { Mouse lung } \\
\text { Mouse lung } \\
\text { Mouse } \\
\text { Rabbit } \\
\text { Rabbit } \\
\text { Mouse lung } \\
\text { Rat lung }\end{array}$ & $\begin{array}{l}\text { R. J. Fallon } \\
\text { D. G. ff. Edward } \\
\text { R. M. Lemcke } \\
\text { W. H. Murphy } \\
\text { R. M. Lemcke } \\
\text { R. M. Lemcke } \\
\text { R. M. Lemcke } \\
\text { G. E. Kenny } \\
\text { G. E. Kenny } \\
\text { J. Tully } \\
\text { R. M. Lemcke }\end{array}$ \\
\hline (2) Freshly isolated strains & $\begin{array}{l}\text { Strain R } \\
\text { M6IE } \\
\text { RBU } \\
\text { BWIL } \\
\text { IOI4NP } \\
\text { G-3 } \\
\text { MacIndoe } \\
\text { Strain G }\end{array}$ & $\begin{array}{l}\text { Rat lung } \\
\text { Mouse ear } \\
\text { Rat nose } \\
\text { Rat nose } \\
\text { Mouse nasopharynx } \\
\text { Rat lung } \\
\text { Rat lung } \\
\text { Rat }\end{array}$ & $\begin{array}{l}\text { A. Hill } \\
\text { A. Hill } \\
\text { A. Hill } \\
\text { A. Hill } \\
\text { A. Hill } \\
\text { A. Hill } \\
\text { A. Hill } \\
\text { A. Hill }\end{array}$ \\
\hline M. neurolyticum & KSA & $\longrightarrow$ & NCTC* \\
\hline$M$. arthritidis & Campo & - & D. G. ff. Edward \\
\hline M. hominis & PG2I & 一 & Burroughs Wellcome \\
\hline M. fermentans & PGI 8 & 一 & Burroughs Wellcome \\
\hline
\end{tabular}

The organisms were harvested at $33400 \mathrm{~g}$ for $30 \mathrm{~min}$ and then washed three times in phosphate buffered saline, each time being centrifuged at $46500 \mathrm{~g}$ for $20 \mathrm{~min}$. The protein content of the suspension was estimated by the method of Lowry, Rosebrough, Farr \& Randall (I95I).

Extraction. The organisms were sedimented at $46500 \mathrm{~g}$ for $20 \mathrm{~min}$ and $0.2 \mathrm{ml}$ phenol-acetic acid-water $(2: \mathrm{I}: 0.5, \mathrm{w} / \mathrm{v} / \mathrm{v})$ mixture was added for each $\mathrm{mg}$ of protein in the pellet, mixed by pipette at intervals over a period of $30 \mathrm{~min}$ at room temperature and held overnight at $4{ }^{\circ} \mathrm{C}$. After centrifugation at $46500 \mathrm{~g}$ for $\mathrm{I} 5 \mathrm{~min}$, the extract, which contained 2 to $4 \mathrm{mg}$ protein $/ \mathrm{ml}$, was stored in screw-capped vials at $4{ }^{\circ} \mathrm{C}$.

Polyacrylamide-gel electrophoresis. The disc electrophoresis apparatus used as P.A.G.E. model 8-PE 34 (35/S) (Quickfit and Quartz Ltd, Stone, Staffordshire). The polyacrylamide gel contained $35 \%(\mathrm{v} / \mathrm{v})$ acetic acid, 5 M-urea and $7.5 \%(\mathrm{w} / \mathrm{v})$ acrylamide (Takayama, MacLennan, Tzagoloff \& Stoner, 1966). The unpolymerized mixture was degassed under vacuum, and $\mathrm{I} \mathrm{ml}$ placed in each $5 \times 65 \mathrm{~mm}$ glass tube and overlaid with $75 \%(\mathrm{v} / \mathrm{v})$ acetic acid. Polymerization of the acrylamide was carried out at $37{ }^{\circ} \mathrm{C}$ for $45 \mathrm{~min}$.

When the gels were firm the overlay and unpolymerized material were removed and the surface was washed with $75 \%$ acetic acid. The tubes were fitted to the holder, each gel was overlaid with $0.08 \mathrm{ml}$ of $75 \%$ acetic acid, and the tubes were filled carefully with $10 \%(\mathrm{v} / \mathrm{v})$ acetic acid, which was also used in the upper and lower reservoirs of the apparatus. The clear extract ( $100 \mu \mathrm{l})$ was mixed with $50 \mu \mathrm{l}$ of a $40 \%$ (w/v) sucrose solution in $35 \%(\mathrm{v} / \mathrm{v})$ acetic acid and was applied to the gel from a micropipette. The sample was allowed to sink slowly through the buffer layers on to the gel surface, thus minimizing mixing with the buffer. The lower electrode served as the cathode. Electrophoresis was started with a total 

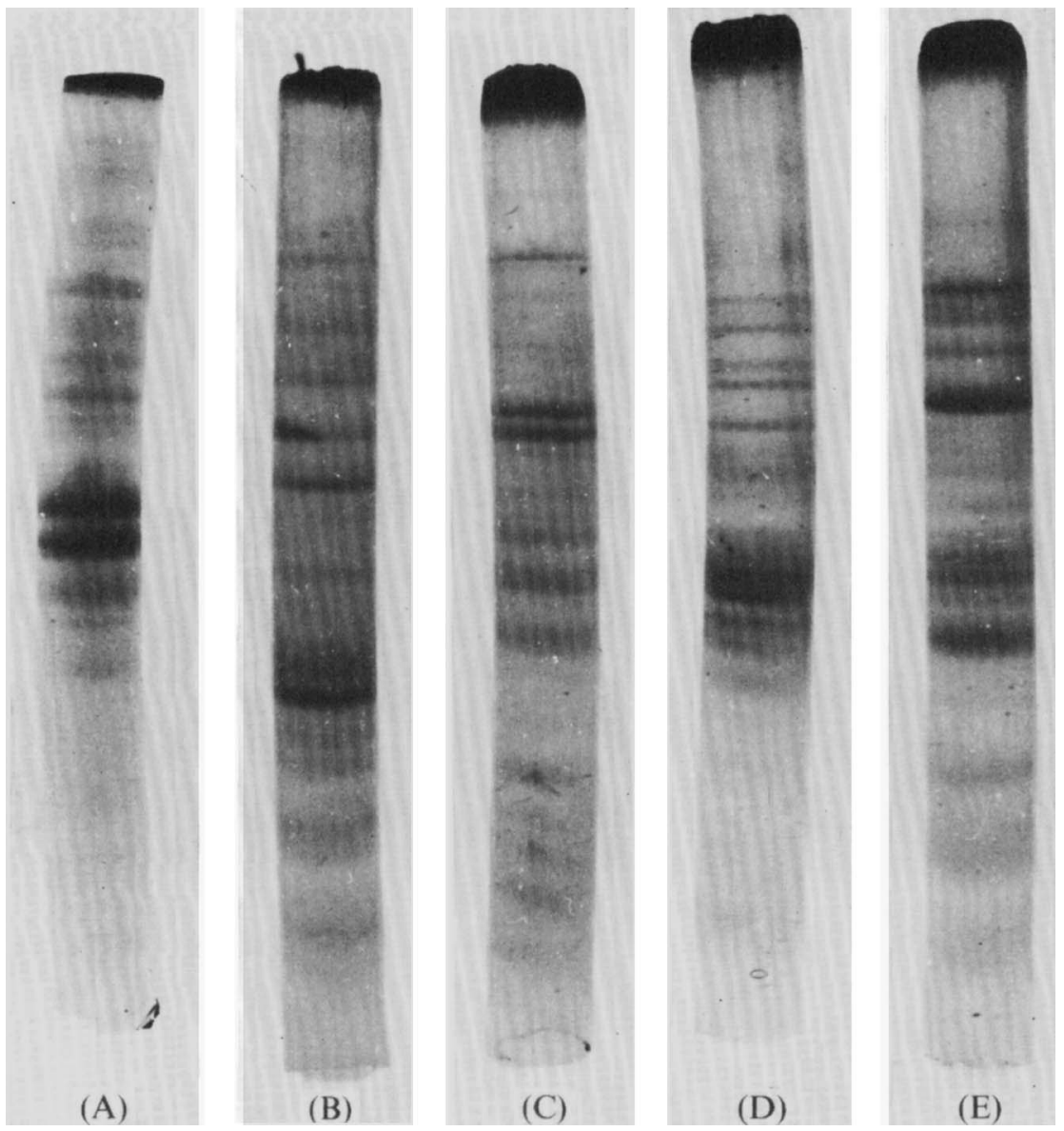

Fig. I. Electrophoretic patterns of cell proteins of (A) Mycoplasma hominis strain PT2 I, (B) $M$. fermentans strain PGI8, (C) $M$. neurolyticum strain KSA, (D) $M$. arthritidis strain Campo, (E) $M$. pulmonis strain Negroni.

current of $2 \mathrm{~mA}$ for $5 \mathrm{~min}$ to settle the proteins at the gel surface and then the current was increased to $4 \mathrm{~mA} /$ tube and run for $3 \mathrm{~h}$ at room temperature.

The gels were removed from the tubes under water and were stained with $\mathrm{I} \%(\mathrm{w} / \mathrm{v})$ Amido Black $\mathrm{I} O \mathrm{~B}$ in $7 \%(\mathrm{v} / \mathrm{v})$ acetic acid for $\mathrm{I} h$. The stain was removed; the gels were rinsed in tap water and held overnight in $7 \%$ acetic acid which helped to fix the proteins in the gel. The background stain was removed electrolytically in $7 \%$ acetic acid using a direct current of $10 \mathrm{~mA} /$ tube for $45 \mathrm{~min}$. The destained gels could be kept for an indefinite period if sealed in $7 \%$ acetic acid and stored away from daylight.

\section{RESULTS}

Factors which might cause variations in the electrophoretic patterns of different extracts of one strain were examined by testing the Negroni strains of Mycoplasma pulmonis under the following conditions.

(I) Several batches, using stock cultures frozen on different dates as seed, were processed and the extracts were compared in one experiment. 

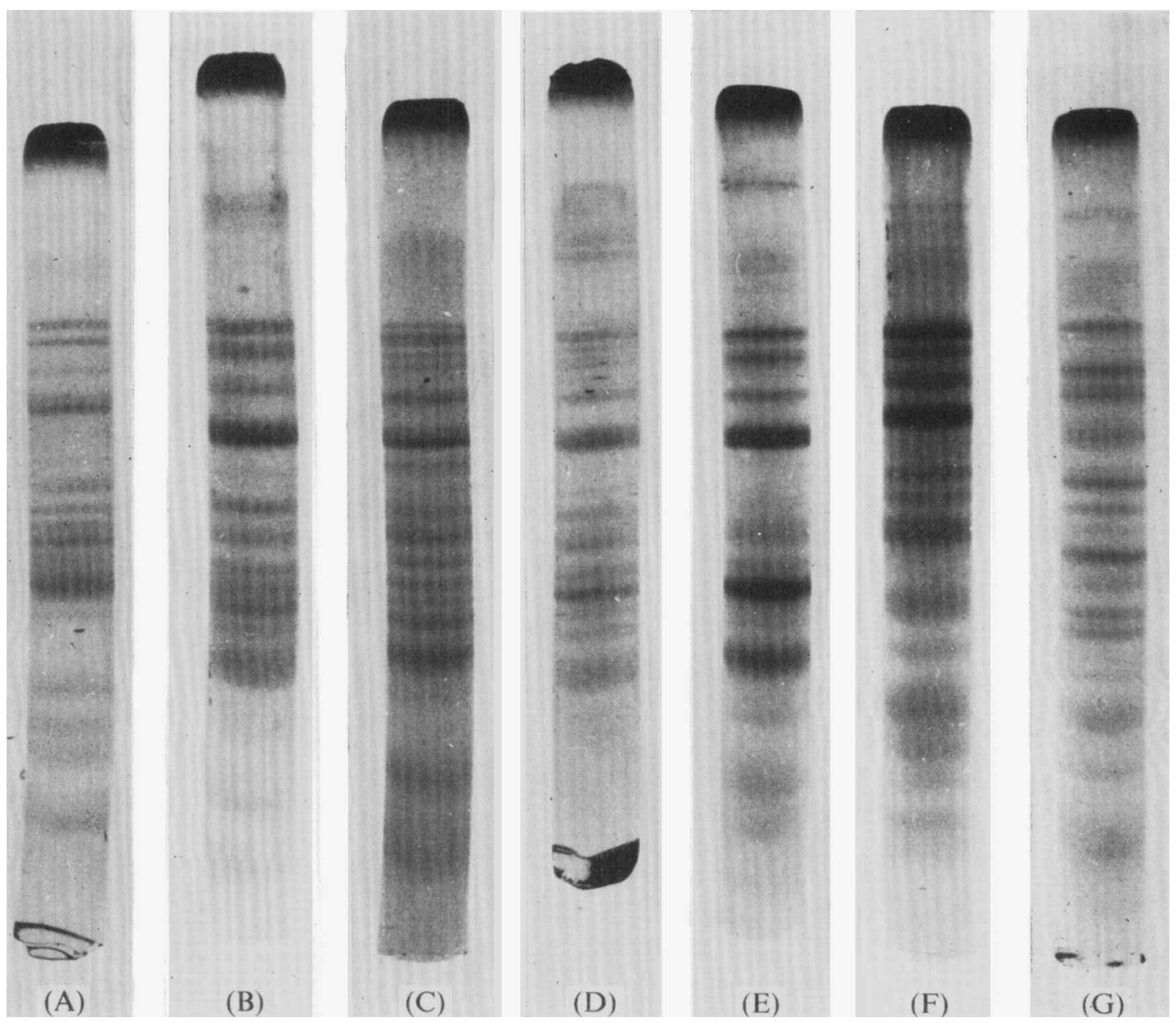

Fig. 2. Electrophoretic patterns of cell proteins of Mycoplasma pulmonis strains representing (A) Group I - strain Ash, (B) Group 2-strain IOI4NP, (C) Group 3-strain Sabin type C, and of individual strains, (D) strain M2, (E) strain 880, (F) strain RBU, (G) strain Kon.

(2) Several extracts were made at one time from one batch of organisms and extracts were also made at intervals from another batch; the extracts were then compared.

(3) Extracts were compared from organisms which had been grown in media containing different batches of horse serum as the only variable, or in media with and without glucose.

(4) The patterns of extracts of organisms of different ages were compared; the patterns of extracts stored at $4{ }^{\circ} \mathrm{C}$ for different periods of time were also compared.

(5) Different clones (obtained by single colony subculture) originating from one frozen stock culture were compared.

(6) The electrophoretic patterns of one extract run on different days were compared.

There was no substantial difference in the patterns of the different extracts which were run on the same day. Conditions of growth and the age of the cells or extracts did not affect the electrophoretic patterns, thus confirming the findings of Razin \& Rottem (I967) and Razin (I968).

Minor variations in the starting-point of the electrophoretic pattern and in the quantity of 
protein applied to the gel occurred. Medium components contributed no lines to the electrophoretic pattern: uninoculated medium was incubated for several days, centrifuged, and the small pellet was extracted and subjected to electrophoresis but gave no lines when the gel was stained.

Electrophoretic patterns of different species. Several human species of mycoplasmas were extracted and compared with rodent strains (Fig. I). Species differentiation was possible, each pattern being distinct, thus confirming the findings of Razin \& Rottem (1967) and Haas, Sacks \& Razin (1968).

Comparison of strains of Mycoplasma pulmonis. The electrophoretic patterns of 19 strains of M. pulmonis were compared after the organisms had been grown and extracted under standard conditions. The patterns were not identical. There was, in most cases, a 'basic $M$. pulmonis pattern', seen particularly in the first four to six lines near the top of the gel. Differences were more distinct in the patterns of some strains than of others; e.g. strain 880 and strain Kon had distinct patterns, but in the case of Kon the pattern of the top group of lines was not very close to the 'basic $M$. pulmonis pattern'.

Three groups of strains were observed (Fig. 2), with some individual strains. Most of the strains possessed electrophoretic patterns which resembled the 'basic Mycoplasma pulmonis pattern'. The patterns of several recent isolates differed from those of long adapted strains of $M$. pulmonis in being more densely stained and more clear-cut. Some had more bands in the pattern particularly in the lower region of the gel. Some recent isolates resembled the adapted strains closely while others were more distinct.

The groups of strains having similar patterns were: Group I - Negroni, M72L, Ash and 63; Group 2-strain G, Cheng 47 clone T, IOI4NP, BWIL, strain G-3; Group 3-M6IE, Sabin type C, Macindoe. The individual strains included Kon, 880, RBU, strain R, M2 and M50.

\section{DISCUSSION}

Only a few mycoplasmal species among those examined to date show significant or distinct differences between strains at the subspecies level. Intraspecies differences between strains of Mycoplasma hominis have been demonstrated by several serological techniques (Nicol \& Edward, 1953; Taylor-Robinson et al. 1965; Purcell et al. 1967; Hollingdale \& Lemcke, 1970). Diversity within the species has also been demonstrated by Somerson et al. (I966), who used a nucleic acid homology technique, and by Razin (I968) and Hollingdale \& Lemcke (1970), who showed that the proteins of strains of $M$. hominis possessed differing patterns in polyacrylamide-gel electrophoresis. Serological evidence of heterogeneity in the species $M$. pulmonis was produced by Leach \& Butler (1966), Fallon \& Jackson (1967) and Deeb \& Keeny (1967). The electrophoretic patterns of proteins of strains of $M$. pulmonis (Razin, 1968) indicated different patterns which might permit division of the species into subtypes. However, nucleic acid homology studies failed to distinguish between strains of $M$. pulmonis (Somerson, Reich, Chanock \& Weissman, 1967). In the present investigation distinct differences were observed between some strains although all strains were identifiable as members of the one species with the exception of Kon, the pattern of which did not closely resemble the 'basic $M$. pulmonis pattern'. Three groups of strains could be distinguished and there were a number of separate strains which possessed the ' $M$. pulmonis pattern' but whose overall pattern differed from those produced by other strains examined.

The groups of strains with similar electrophoretic patterns were not the same as those formed from the results of serological studies (Forshaw \& Fallon, 1972). This is not unexpected since quite different systems were being analysed and accords with the findings of 
Taylor-Robinson, Martin-Bourgon, Watanabe \& Addey (I97I) with T-strain mycoplasmas. More detailed consideration of these findings and their relationship to the classification of Mycoplasma pulmonis is made in the discussion of the accompanying paper (Forshaw \& Fallon, 1972) in which the results of serological examination of $M$. pulmonis strains are presented.

This work was carried out during the author's tenure of the Sir Maurice Bloch Research Fellowship at the Department of Infectious Diseases, Glasgow University. The materials and most of the equipment used in this investigation were provided by the Secretary of State for Scotland from a grant made on the recommendation of the Advisory Committee on Medical Research to Dr R. J. Fallon. I wish to thank the investigators who kindly supplied cultures for study and Professor S. Alstead, late of the Department of Materia Medica, Stobhill Hospital, for photographic facilities.

\section{REFERENCES}

Chanock, R. M., James, W. D., Fox, H. H., Turner, H. C., Mufson, H. A. \& Hayflick, L. (1962). Growth of Eaton PPLO in broth and preparation of complement fixing antigen. Proceedings of the Society for Experimental Biology and Medicine 110, 884-888.

CLYDE, W. A. (1964). Mycoplasma species identification based upon growth inhibition by specific antisera. Journal of Immunology 92, 958-965.

DeEB, B. J. \& KenNy, G. E. (1967). Characterization of Mycoplasma pulmonis variants isolated from rabbits. II. Basis for differentiation of antigenic subtypes. Journal of Bacteriology 93, I425-I429.

FALLON, R. J. (1969). Isolation methods for mycoplasma from man and rodents. In Isolation Methods for Microbiologists. Society for Applied Bacteriology Technical Series 3, pp. 4I-50. Edited by D. A. Shapton and G. W. Gould. London and New York: Academic Press.

FALLON, R. J. \& JACKSON, D. K. (1967). The relationship between a rodent mycoplasma, Mycoplasma pulmonis, and certain mycoplasmas isolated from tissue cultures inoculated with material from patients with leukaemia. Laboratory Animals 1, 55-64.

Forshaw, K. A. \& Fallon, R. J. (1972). Serological heterogeneity of Mycoplasma pulmonis. Journal of General Microbiology 72, 50I-5IO.

Fowler, R. C., Coble, D. W., Kramer, N. C. \& Brown, T. M. (1963). Starch gel electrophoresis of a fraction of certain of the pleuro-pneumonia-like group of microorganisms. Journal of Bacteriology 86, I 145 - I 15 I.

HAAS, H., SACKS, T. G. \& RAZIN, S. (1968). Identification of mycoplasmas of human origin. Journal of General Microbiology 52, I19-124.

Hollingdale, M. R. \& LemCKe, R. M. (1970). Antigenic differences within the species Mycoplasma hominis. Journal of Hygiene 68, 469-477.

LEACH, R. H. \& BUtLER, M. (I966). Comparison of mycoplasmas associated with tumours, leukaemia and tissue cultures. Journal of Bacteriology 91, 934-94I.

Lowry, O. H., Rosebrough, N. J., Farr, A. L. \& Randall, R. J. (I95I). Protein measurements with the Folin phenol reagent. Journal of Biological Chemistry 193, 265-275.

NicoL, C. S. \& EDWARD, D. G. FF. (1953). Role of organisms of the pleuropneumonia group in human genital infections. British Journal of Venereal Diseases 29, I4I-I 50.

Purcell, R. H., Taylor-Robinson, D., Canchola, J., Wong, D., Valdesuso, J. \& Chanock, R. M. (1967). Significance of antibody to mycoplasmas as measured by metabolic inhibition techniques. Annals of the New York Academy of Sciences 143, 664-675.

RAZIN, S. (1968). Mycoplasma taxonomy studied by electrophoresis of cell proteins. Journal of Bacteriology 96 , 687-694.

RAZIN, S. \& RotTeM, S. (1967). Identification of Mycoplasma and other microorganisms by polyacrylamidegel electrophoresis of cell proteins. Journal of Bacteriology 94, I 807-1810.

RotTEM, S. \& RAZIN, S. (1967). Electrophoretic patterns of membrane proteins of Mycoplasma. Journal of Bacteriology 94, 359-364.

Somerson, N. L., Reich, P. R., Chanock, R. M. \& Weissman, S. M. (1967). Genetic differentiation by nucleic acid homology. III. Relationships among mycoplasma, L-forms and bacteria. Annals of the New York Academy of Sciences 143, 9-20. 
Somerson, N. L., Reich, P. R., Walls, B. E., Chanock, R. M. \& Weissman, S. M. (I966). Genetic differentiation by nucleic acid homology. II. Genetic variations within two mycoplasma species. Journal of Bacteriology 92, 3I I-3I7.

Takayama, K., Maclennan, D. H., Tzagoloff, A. \& Stoner, C. D. (1966). Studies on the electron transfer system LXVII. Polyacrylamide gel electrophoresis of the mitochondrial electron transfer complexes. Archives of Biochemistry and Biophysics $1 \mathbf{4}, 223-230$.

Taylor-Robinson, D., Ludwig, W. M., Purcell, R. H., Mufson, M. A. \& Chanock, R. M. (I965). Significance of antibody to Mycoplasma hominis type I as measured by indirect haemagglutination. Proceedings of the Society for Experimental Biology and Medicine 118, 1073-1082.

Taylor-Robinson, D., Martin-Bourgon, C., Watanabe, T. \& Addey, J. P. (I97I). Isolation of T-mycoplasmas from dogs and squirrel monkeys; biological and serological comparison with those isolated from man and cattle. Journal of General Microbiology 68, 97-107. 